\title{
CROP MANAGEMENT SYSTEMS AND MAIZE GRAIN YIELD UNDER NARROW ROW SPACING
}

\author{
Mércio Luiz Strieder ${ }^{1}$; Paulo Regis Ferreira da Silva ${ }^{1 *}$; Lisandro Rambo ${ }^{2}$; Luís Sangoi; \\ Adriano Alves da Silva ${ }^{1}$; Paulo César Endrigo ${ }^{1}$; Douglas Batista Jandrey ${ }^{1}$ \\ ${ }^{1}$ UFRGS - Depto. de Plantas de Lavoura, C.P. 15100 - 90001-970 - Porto Alegre, RS - Brasil. \\ ${ }^{2}$ Syngenta Seeds - Desenvolvimento de Produtos, Rod. BR 452, km 142 - 38400-974 - Uberlândia - MG, Brasil. \\ ${ }^{3}$ UDESC - Depto. de Fitotecnia, C.P. 281 - 88520-000 - Lages, SC - Brasil. \\ *Corresponding author < paulo.silva@ufrgs.br>
}

\begin{abstract}
Reduction in row spacing provides a more uniform distribution among plants that can increase grain yield. The benefits of narrow row spacing can depend on the plant architecture and on the kind of crop management system. The objective of this study was to assess the effects of narrow row spacing on the grain yield of maize hybrids growing under different management systems. Six experiments were carried out in Eldorado do Sul, State of Rio Grande do Sul, Brazil, during the 2003/04 and 2004/05 growing seasons. Each experiment corresponded to a crop management system. Treatments consisted of two row spacings (0.8 and $0.4 \mathrm{~m}$ ), two hybrids (Penta and Flash) and two plant densities, which varied with the crop management system and growing season. Besides plant density, the crop management systems differed in the quantities of fertilizers applied at sowing, side-dress and use of irrigation. A complete randomized block design was used in each experiment, in a $2 \times 2 \times 2$ treatment factorial scheme with four replications. The increases in grain yield with narrow row spacing were small, ranging from zero to $14 \%$. They depended on the growing season and were manifested only with yields higher than $10 \mathrm{t} \mathrm{ha}^{-1}$, regardless of the hybrid. The number of grains per area was the component that best explained the response of grain to narrow row spacing, regardless of plant density, hybrid and crop management system. Narrow row spacing is a worth management strategy to enhance maize grain yield when high input cropping systems are used.
\end{abstract}

Key words: Zea mays, plant arrangement, hybrid, yield components, fertility and irrigation levels

\section{SISTEMAS DE MANEJO E PRODUTIVIDADE DE GRÃOS DE MILHO SOB ESPAÇAMENTO ENTRELINHAS REDUZIDO}

RESUMO: A redução do espaçamento entrelinhas melhora a distribuição entre plantas na área e pode incrementar a produtividade de grãos. Os benefícios da redução do espaçamento entrelinhas podem depender da arquitetura de planta e do sistema de manejo empregado. A pesquisa objetivou avaliar os efeitos da redução do espaçamento entrelinhas na produtividade de grãos de híbridos de milho cultivados em diferentes sistemas de manejo. Seis experimentos foram conduzidos a campo, em Eldorado do Sul-RS, nos anos agrícolas 2004/05 e 2005/06. Cada experimento correspondeu a um sistema de manejo. Os tratamentos constaram de dois espaçamentos (0,8 e 0,4 m), dois híbridos (Penta e Flash) e duas densidades de plantas, variáveis com o sistema de manejo e anos agrícolas. Além da densidade, os sistemas de manejo diferiram nas quantidades aplicadas de adubo na semeadura, em cobertura e na suplementação hídrica. Em cada experimento, o delineamento experimental foi o de blocos casualizados, em fatorial $2 \times 2 \times 2$, com quatro repetições. Os incrementos na produtividade de grãos com redução do espaçamento foram de pequena magnitude, variando de 0 a 14\%. Eles dependeram da estação de crescimento e se manifestaram apenas com produtividades superiores a $10 \mathrm{t} \mathrm{ha}^{-1}$, independente do híbrido. O número de grãos por área foi o componente que melhor explicou a resposta da produtividade com redução do espaçamento, independentemente de densidade, híbrido e sistema de manejo. A redução do espaçamento é uma estratégia de manejo válida para incrementar a produtividade de grãos quando são adotados níveis de manejo muito altos.

Palavras-chave: Zea mays, arranjo de plantas, híbrido, componentes da produção, níveis de fertilidade e irrigação

\section{INTRODUCTION}

The photosynthetically active solar radiation intercepted $\left(\mathrm{PAR}_{\mathrm{int}}\right)$ by the canopy is one of the main requirements to obtain high yields in the absence of water shortage (Melges et al., 1989). A strategy to in- 
crease $\mathrm{PAR}_{\text {int }}$ is the choice of plant arrangement, one of the crop management practices that most influences grain yield and that can be manipulated by modifying row spacing, density and plant distribution in the row (Ottman \& Welch, 1989; Loomis \& Amthor, 1999; Argenta et al., 2001b; Silva et al., 2006).

The benefits and limitations of narrow row spacing for maize have been widely discussed during the last ten years. Some advantages of reducing row spacing include the more efficient use of environmental resources, better weed control and higher grain yield. However, many studies with narrow row spacing in maize have shown small increases (zero to 10\%) in grain yield compared to conventional spacing (Sangoi, 1990; Sangoi et al., 1998 and 2001; Teasdale, 1998; Argenta et al., 2001a; Flesch \& Vieira, 2004). These small size responses indicate that other factors may limit the advantages of using narrow row to increase grain yield, such as hybrid architecture and management system.

Modern maize hybrids tolerate higher plant densities than hybrids used in the past (Duvick \& Cassmann, 1999; Tollenaar \& Lee, 2002; Sangoi et al., 2002), and the use of narrow rows has greater potential to enhance grain yield at crowded stands (Silva et al., 2006; Sangoi \& Silva, 2006).

Considering the alterations introduced by breeding programs in recent hybrids, the hypothesis of this study was that there would be a positive response to narrow row spacing, especially in situations where high grain yield levels are accomplished and other limiting factors, besides those related to plant distribution, are met. The objective of this study was to assess the effects of narrow row spacing on grain yield, its components and on other agronomic characteristics of two maize hybrids, cultivated under three crop management systems and two plant densities.

\section{MATERIALAND METHODS}

Six field experiments were carried out in Eldorado do Sul State of Rio Grande do Sul, Brazil $\left(30^{\circ} 05^{\prime} \mathrm{S}, 51^{\circ} 40^{\prime} \mathrm{W}\right.$, mean altitude $\left.46 \mathrm{~m}\right)$, three in 2003/04 and three in 2004/05. The climate of the region is humid subtropical, with $1,446 \mathrm{~mm}$ mean annual rainfall and $426 \mathrm{~mm}$ concentrated from November to February (Bergamaschi et al., 2003). This period includes flowering, grain formation and grain filling of maize when sown in the first 15 days of October. The soil was classified as a typical dystrophic red clay soil (Embrapa, 1999) and has been cultivated for the last 13 years under the no till system, with soybean and maize rotation in the summer. The physical and chemical attributes of the soil are: clay content: $338 \mathrm{~g} \mathrm{~kg}^{-1}$; $\mathrm{pH}$ in water: 5.2 ; available P: $6.1 \mathrm{mg} \mathrm{L}^{-1}$; available K: $167 \mathrm{mg} \mathrm{L}^{-1}$; organic matter: $23 \mathrm{~g} \mathrm{~kg}^{-1}$ and cationic exchange capacity: $87 \mathrm{mmol}_{\mathrm{c}} \mathrm{L}^{-1}$ (Tedesco et al., 1995). Phosphorus and potassium soil contents were extracted through the Mehlich I method.

In the two growing seasons, each of the three crop management systems (medium, high and very high) corresponded to one experiment. The treatments consisted of two row spacings (0.4 and $0.8 \mathrm{~m})$, two hybrids (Flash, with erect leaves and Penta with flattened leaves) and two plant densities, which varied with the crop management system and growing season (Table 1). In the six experiments, a complete randomized block design was used in a $2 \times 2 \times 2$ treatment factorial scheme $(n=4)$. The two genotypes were Flash and Penta, single-cross hybrids with very early and early cycles, respectively. Besides the plant density, the crop management systems differed regarding the quantity of fertilizer applied at sowing and sidedress, and in the use of irrigation (Table 1). The fertilizer levels and plant densities used in the medium and high crop management systems were based on the

Table 1 - Characteristics of the three maize crop management systems in each growing season.

\begin{tabular}{|c|c|c|c|c|c|c|c|}
\hline \multirow{3}{*}{$\begin{array}{l}\text { Crop management } \\
\text { system }\end{array}$} & & & \multicolumn{4}{|c|}{ Mineral fertilizers } & \multirow{3}{*}{$\begin{array}{l}\text { Supplemental } \\
\text { irrigation }\end{array}$} \\
\hline & \multicolumn{2}{|c|}{ Plant density } & \multicolumn{2}{|r|}{$\mathrm{N}$} & $\mathrm{P}_{2} \mathrm{O}_{5}$ & $\mathrm{~K}_{2} \mathrm{O}$ & \\
\hline & $2003 / 04$ & $2004 / 05$ & Sowing & Side-dress & \multicolumn{2}{|c|}{ Sowing } & \\
\hline & \multicolumn{2}{|c|}{--- plant $\mathrm{m}^{-2}$-..- } & - & kq & $\cdots$ & (n- & \\
\hline \multirow[t]{2}{*}{ Medium } & 4.5 & 5.0 & 10 & 60 & 40 & 40 & Without $^{1 /}$ \\
\hline & 6.0 & 6.6 & 10 & 60 & 40 & 40 & \\
\hline \multirow[t]{2}{*}{ High } & 5.5 & 6.2 & 20 & 120 & 95 & 95 & With \\
\hline & 7.0 & 8.3 & 20 & 120 & 95 & 95 & \\
\hline \multirow[t]{2}{*}{ Very high } & 6.5 & 7.5 & 40 & 185 & 130 & 130 & With \\
\hline & 8.0 & 9.9 & 40 & 185 & 130 & 130 & \\
\hline
\end{tabular}

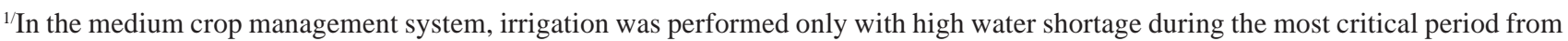
14 days before $\left(\mathrm{V}_{15}\right.$ stage) to twenty days after flowering $\left(\mathrm{R}_{3}\right.$ stage). 
technical recommendations for maize of the states RS and SC (CQFS RS/SC, 2004; Reunião, 2005). The two experiments with very high crop management system, were based on trials conducted previously at the same place by Argenta et al. (2003) and by Forsthofer et al. (2006).

Maize was sown on 21 October 2003 and 13 October 2004. Plant densities were adjusted to the required values 14 days after seedling emergence, at the $\mathrm{V}_{2}$ stage, following the development scale proposed by Ritchie et al. (1993). In all the crop management systems, the sowing and side-dress fertilizers were performed by hand on the row. At sowing, it consisted of a mixture of urea $(45 \% \mathrm{~N})$, triple super phosphate $\left(42 \% \mathrm{P}_{2} \mathrm{O}_{5}\right)$ and potassium chloride $\left(60 \% \mathrm{~K}_{2} \mathrm{O}\right)$ and for side-dressing just urea. The rates of each applied fertilizer are described in Table 1 . The $\mathrm{N}$ levels applied on side-dressings varied with the crop management system. Thus, in the medium crop management system 60 $\mathrm{kg} \mathrm{ha}{ }^{-1}$ were applied at the five expanded leaf stage $\left(\mathrm{V}_{5}\right)$. In the high crop management system, 50 and $70 \mathrm{~kg}$ ha ${ }^{1}$ of $\mathrm{N}$ were side-dressed at the $\mathrm{V}_{4}$ and $\mathrm{V}_{10}$ stages, respectively. In the very high crop management system, 45, 65 and $75 \mathrm{~kg} \mathrm{ha}^{-1}$ of $\mathrm{N}$ were applied at the $\mathrm{V}_{3}, \mathrm{~V}_{9}$ and pre-flowering stages, respectively.

During the two years the meteorological data to calculate the water balance were obtained from a meteorological unit located at $1.3 \mathrm{~km}$ from the experimental area. Although only the data regarding the period between October and March are presented for each growing season, the water balance was calculated between September and April, considering $75 \mathrm{~mm}$ as available water capacity in soil. In the high and very high crop management systems, maize irrigation requirements were considered similar. They were estimated by the installation of three tensiometers at 0.2 $\mathrm{m}$ and three at $0.4 \mathrm{~m}$ depth in three replicates. In the medium crop management system, irrigation was carried out only when there was great water shortage during the most critical period, between 15 days before the booting $\left(\mathrm{V}_{15}\right)$ and 20 days after flowering $\left(\mathrm{R}_{3}\right)$. Whenever the water potential in the soil was less than $-0.04 \mathrm{MPa}$, sprinkle irrigation was applied at the rate of $8 \mathrm{~mm} \mathrm{~h}^{-1}$. Weeds and pests were controlled equally in all experiments not to affect crop performance.

Grain yield, its components and kernel crude protein content were determined. Grain yield was assessed in the three central lines of each experimental unit of $0.8 \mathrm{~m}$ row spacing and in the six central lines on the $0.4 \mathrm{~m}$ row spacing, excluding $0.5 \mathrm{~m}$ at each row end, comprising an experimental area of $9.6 \mathrm{~m}^{2}$. Values of grain weight were corrected to the standard moisture of $13 \%$, and extrapolated to one hectare. The number of ears per area was estimated by the ratio between the number of ears collected in the plot and the respective useful area. The mass of one grain was obtained by counting and weighting samples of 400 grains. The number of grains per area was estimated by the ratio between grain mass of the plot and the mass of one grain. The kernel crude protein content was determined by grinding a 20 g grain sample from the plot to obtain the $\mathrm{N}$ content and multiplying the value by 6.25 ( $1 \% \mathrm{~N}$ corresponds to $6.25 \mathrm{~g}$ protein) (Tedesco et al., 1995).

The data from each experiment were submitted to the analysis of variance by the F test $(p<0.05)$. When statistical significance was reached, the means of the treatments were compared by the DMS test $(p<0.05)$, all proceeded using the Statistical Analysis System (SAS Institute, 1996) for balanced data (PROC ANOVA). Data from each crop management system, for each growing season, were analyzed individually as one experiment, according to the characteristics of the treatments and the proposed objectives. Because the objectives of this study here we only shown the results of simple effects of narrow spacing or its interaction with plant density or with the hybrid.

\section{RESULTS AND DISCUSSION}

The water shortage observed during most maize cycles was greater than the historic mean of the region at both growing seasons. In the first year, there were water shortages ranging from 10 to $40 \mathrm{~mm}$ at stage $V_{6}$, between stages $V_{15}$ and $R_{3}$ and between $R_{4}$ and $\mathrm{R}_{6}$ (Figure 1 ). In the second year, the water shortage was even more intense than in the first, especially

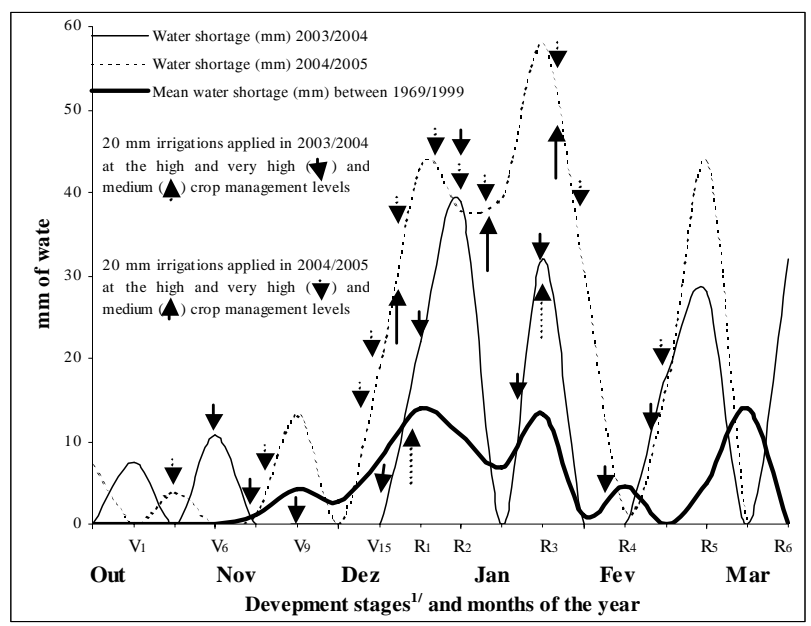

Figure 1 - Water shortages at 10-day intervals throughout maize cycle for three crop management systems, relative to two growing seasons and the historic mean between 1969/1999, in Eldorado do Sul-RS. Data obtained from the agricultural meteorological department of FA/ UFRGS. ${ }^{1 /}$ According to the development scale proposed by Ritchie et al. (1993). 
during the reproductive period $\left(\mathrm{R}_{1}\right.$ to $\left.\mathrm{R}_{6}\right)$. Water deficits varied from 10 and $55 \mathrm{~mm}$ among the $\mathrm{V}_{12}$ and $\mathrm{R}_{3}$ stages and in $\mathrm{R}_{5}$. Because of the irregular rainfall below the demands of the crop, in the experiments with high and very high crop management ten irrigations of $20 \mathrm{~mm}$ were made in the first year, distributed throughout the cycle. In the second year, 11 irrigations were performed, eight of which concentrated between the $\mathrm{V}_{12}$ and $\mathrm{R}_{4}$ stages. In the two years, irrigation supplied most of the plant water demand. However, adequate water availability may not have been sufficient for full plant development, because temperature, relative air humidity and the nutritional state also affect maize metabolism and plant growth.

The low water availability during the maize cycle reduces grain yield in several cropping regions, the great losses occurring between 15 days before $\left(\mathrm{V}_{15}\right)$ and 20 days after flowering $\left(\mathrm{R}_{3}\right)$, because during this period of the cycle the atmospheric evaporation is of the order of $8 \mathrm{~mm}^{-1 a y^{-1}}$ (Matzenauer \& Machado, 2002) in our study area. In other studies with maize (Silva et al., 1999), it was verified that in time the reduction in grain yield occurs mainly due to increases in the anthesis-silking interval, which reduces the number of grains per plant. In Eldorado do SulRS, water shortage throughout the maize cycle may occur in more than $60 \%$ of the years (Matzenauer \& Machado, 2002). Under these conditions, the maize grain yield shows that adequate water distribution during the critical period is more important than the total quantity of rainfall and/or irrigation throughout the cycle. These results are in agreement with those reported by Matzenauer \& Machado (2002) when studying water availability for maize in years of different rainfall in Eldorado do Sul-RS. Thus, the adoption of irrigation may be considered an essential practice to obtain high maize grain yield in the main cropping regions of Brazil.

\section{Medium crop management system}

In the medium crop management system, corresponding to the decrease of row spacing from 0.8 to $0.4 \mathrm{~m}$ did not affect grain yield, regardless of plant density, hybrid or growing season (Table 2). In the 2003/04 growing season, the average grain yield was $8.1 \mathrm{t} \mathrm{ha}^{-1}$ in the two row spacings and in the second year, yield values were lower, 2.1 and $2.3 \mathrm{t} \mathrm{ha}^{-1}$, respectively, in the smaller and greater row spacing (Table 2). In both years, the response of grain yield components to narrow row spacing did also not depend on plant density or hybrid (Table 2). However, in 2003/04 the reduction of row spacing from 0.8 to $0.4 \mathrm{~m}$ increased the number of ears per area (13\%), decreased grain mass (5\%), but did not alter the num- ber of grains per area. In the second year, row spacing did not influence any of the grain yield components, regardless of plant density or hybrid.

The kernel crude protein content was 22\% lower in the $0.4 \mathrm{~m}$ row spacing compared to the 0.8 $\mathrm{m}$ spacing during the first growing season, but only in the low plant density $\left(4.5 \mathrm{pl} \mathrm{m}^{-2}\right)$ (Table 3). There was an inverse response in the second year, with increases of 10 and $16 \%$ in kernel crude protein content for both hybrids, respectively, when row spacing was reduced to $0.4 \mathrm{~m}$ (Table 3). The increase in plant density from 4.5 to $6.0 \mathrm{pl} \mathrm{m}^{-2}$ reduced by $19 \%$ the kernel crude protein content only in the greater row spacing, in 2003/04.

\section{High crop management system}

The average grain yield in the experiments with high crop management system were 11.8 and $9.1 \mathrm{t} \mathrm{ha}^{-1}$, respectively, in the first and second years. In 2003/2004, row spacing reduction from 0.8 to $0.4 \mathrm{~m}$ increased grain yield (10\%), the number of ears (12\%) and grains per area (15\%) and reduced grain mass $(12 \%)$, regardless of plant density or hybrid (Table 2). In 2004/2005, row spacing did not affect grain yield and its components, regardless of plant density or hybrid (Table 2).

In the first year, row spacing reduction from 0.8 to 0.4 m promoted a $27 \%$ increase in Penta kernel crude protein content (Table 3). Penta had also a 20\% higher kernel crude protein content than Flash in the smaller row spacing. An inverse response was observed in the larger row spacing, in which Flash presented a $13 \%$ edge over Penta. In the second year, kernel crude protein content did not vary with row spacing.

\section{Very high crop management system}

When a very high crop management system was adopted, row spacing reduction from 0.8 to $0.4 \mathrm{~m}$ increased grain yield (5\%) and the number of grains per area (4\%) in 2003/2004 (Table 2). In the second year, the narrow row spacing increased grain yield from 9.8 to $11.2 \mathrm{t} \mathrm{ha}^{-1}$ (14\%) for the plant density of $9.9 \mathrm{pl} \mathrm{m}^{-2}$, and no effect was observed for the density of $7.5 \mathrm{pl} \mathrm{m}^{-2}$. Increase in plant density from 7.5 to $9.9 \mathrm{pl} \mathrm{m}^{-2}$ enhanced grain yield from 9.6 to 11.2 $\mathrm{t} \mathrm{ha}^{-1}(17 \%)$ only in the smaller row spacing $(0.4 \mathrm{~m})$. As well as verified in the second year of the medium and high crop management systems, in the very high management systems the grain yield components did also not vary with row spacing (Table 2). In both years, kernel crude protein content was not affected by row spacing, regardless of plant density or hybrid.

Differences in grain yield between growing seasons for the three crop management systems can be attributed to greater water shortage (Figure 1) and 
Table 2 - Maize grain yield and its components in three crop management systems and two growing seasons as a function of row spacing, considering the mean of two plant densities and two hybrids ${ }^{1}$.

\begin{tabular}{|c|c|c|c|}
\hline \multirow{2}{*}{ Growing season } & \multirow{2}{*}{ Grain yield and its components } & \multicolumn{2}{|c|}{ Row spacing } \\
\hline & & 0.4 & 0.8 \\
\hline & & 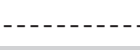 & $-\cdots-\cdots$ \\
\hline \multicolumn{4}{|c|}{ Medium management system } \\
\hline \multirow[t]{4}{*}{ 2003/04 } & Grain yield $\left(\mathrm{t} \mathrm{ha}^{-1}\right)$ & $8.1^{\mathrm{NS}}$ & 8.1 \\
\hline & Ears $\mathrm{m}^{-2}\left(\mathrm{n}^{\mathrm{o}}\right)$ & $6.0 \mathrm{a}$ & $5.3 \mathrm{~b}$ \\
\hline & Grains $\mathrm{m}^{-2}\left(\mathrm{n}^{\mathrm{o}}\right)$ & $2860^{\mathrm{NS}}$ & 2749 \\
\hline & Grain mass (mg) & $282 \mathrm{~b}$ & 296 a \\
\hline \multirow[t]{5}{*}{$2004 / 05$} & Grain yield $\left(t h^{-1}\right)$ & $2.1^{\mathrm{NS}}$ & 2.3 \\
\hline & Ears $\mathrm{m}^{-2}\left(\mathrm{n}^{\mathrm{o}}\right)$ & $4.6^{\mathrm{NS}}$ & 4.2 \\
\hline & Grains $m^{-2}\left(n^{o}\right)$ & $1015^{\mathrm{NS}}$ & 925 \\
\hline & Grain mass (mg) & $231^{\mathrm{NS}}$ & 230 \\
\hline & \multicolumn{3}{|c|}{ High management system } \\
\hline \multirow[t]{4}{*}{$2003 / 04$} & Grain yield $\left(\mathrm{t} \mathrm{ha}^{-1}\right)$ & $12.3 \mathrm{a}$ & $11.2 \mathrm{~b}$ \\
\hline & Ears $\mathrm{m}^{-2}\left(\mathrm{n}^{\mathrm{o}}\right)$ & $7.5 \mathrm{a}$ & $6.5 \mathrm{~b}$ \\
\hline & Grains $m^{-2}\left(n^{\circ}\right)$ & 4066 a & $3620 \mathrm{~b}$ \\
\hline & Grain mass (mg) & $303 \mathrm{~b}$ & 310 a \\
\hline \multirow[t]{5}{*}{$2004 / 05$} & Grain yield $\left(\mathrm{t} \mathrm{ha}^{-1}\right)$ & $8.6^{\mathrm{NS}}$ & 9.6 \\
\hline & Ears $\mathrm{m}^{-2}\left(\mathrm{n}^{\mathrm{o}}\right)$ & $8.7^{\mathrm{NS}}$ & 9.1 \\
\hline & Grains $m^{-2}\left(n^{0}\right)$ & $3136^{\mathrm{NS}}$ & 3050 \\
\hline & Grain mass (mg) & $274^{\mathrm{NS}}$ & 290 \\
\hline & \multicolumn{3}{|c|}{$\begin{array}{l}\text { Very high management system } \\
\end{array}$} \\
\hline \multirow[t]{4}{*}{ 2003/04 } & Grain yield $\left(\mathrm{t} \mathrm{ha}^{-1}\right)$ & $14.3 \mathrm{a}$ & $13.6 \mathrm{~b}$ \\
\hline & Ears $\mathrm{m}^{-2}\left(\mathrm{n}^{\circ}\right)$ & $7.6^{\mathrm{NS}}$ & 7.4 \\
\hline & Grains $m^{-2}\left(n^{0}\right)$ & 4453 a & $4282 \mathrm{~b}$ \\
\hline & Grain mass (mg) & $321^{\mathrm{NS}}$ & 322 \\
\hline \multirow[t]{3}{*}{$2004 / 05$} & Ears $\mathrm{m}^{-2}\left(\mathrm{n}^{\mathrm{o}}\right)$ & $8.4^{\mathrm{NS}}$ & 8.3 \\
\hline & Grains $\mathrm{m}^{-2}\left(\mathrm{n}^{\mathrm{o}}\right)$ & $3480^{\mathrm{NS}}$ & 3404 \\
\hline & Grain mass (mg) & $292^{\mathrm{NS}}$ & 298 \\
\hline
\end{tabular}

${ }^{1}$ In each crop management system means followed by different letters on the line differ by DMS's test $(p<0.05)$; ${ }^{\text {ns }}$ No significative by DMS's test $(p<0.05)$.

the increased plant density (Table 1) observed in the second year. For the three crop management systems, in the 2004/05 growing season the interval between the smallest and highest plant density was 33\% (1.6 to $2.4 \mathrm{pl} \mathrm{m}^{-2}$ ), while in the first year the variation between the two densities was between 23\% to 33\% (1.5 $\mathrm{pl} \mathrm{m}^{-2}$ ) (Table 1). Thus, in the second year the plant density intervals were more uniform between the three crop management systems. Specially for the medium crop management system and in the second year, the greater water shortage that occurred throughout the maize cycle (Figure 1) and the higher plant density caused higher reduction in grain yield. According to Madonni \& Otegui (2004), as density increases, the number of dominated plants also increases, characterized by slow development, small stem diameter and reduced grain yield. As there was less rainfall in the second than in the first year, in the medium crop management system the correct strategy would have been to use lower plant population and not higher density as occurred in the present study, specially because the absence of water supplementation. However, plant density was defined before maize was sown and the water deficit intensity could not be foreseen.

The grain yield differences among crop management systems showed the marked response of maize to changes in field cropping practices. The increases in fertilizer quantity and plant density and the use of irrigation enhanced yield values from the medium to the high and very high management system at both growing seasons, which is corroborated by results reported by Argenta et al. (2003) in the same region. 
Table 3 - Kernel crude protein content in the medium and in the high crop management system as a function of two row spacing and two plant densities and two hybrids in the two years ${ }^{1}$.

\begin{tabular}{|c|c|c|}
\hline \multirow{2}{*}{ Plant density/Hybrid } & \multicolumn{2}{|c|}{ Row spacing $(\mathrm{m})$} \\
\hline & 0.4 & 0.8 \\
\hline \multicolumn{3}{|c|}{ - } \\
\hline \multicolumn{3}{|c|}{ Medium crop management system - 2003/04 } \\
\hline 4.5 & $9.8 \mathrm{Ab}$ & $12.6 \mathrm{Aa}$ \\
\hline 6.0 & $9.7 \mathrm{Aa}$ & $10.2 \mathrm{Ba}$ \\
\hline \multicolumn{3}{|c|}{ Medium crop management system - 2004/05 } \\
\hline Flash & $10.8 \mathrm{Aa}$ & $9.8 \mathrm{Ab}$ \\
\hline Penta & $10.3 \mathrm{Aa}$ & $8.9 \mathrm{Bb}$ \\
\hline \multicolumn{3}{|c|}{ High crop management system - 2003/04 } \\
\hline Flash & $9.2 \mathrm{Ba}$ & $10.3 \mathrm{Aa}$ \\
\hline Penta & $11.6 \mathrm{Aa}$ & $9.1 \mathrm{Bb}$ \\
\hline
\end{tabular}

${ }^{1}$ For each interaction and growing season, means followed by the same lower case letter in the line and means followed by the same uppercase letter on the column, did not differ by DMS's test $(p<0.05)$.

Positive effects of row spacing reduction on grain yield occurred in three of the six experiments and did not depend on the hybrid (Table 2). The more uniform spatial distribution among plants with narrow row spacing, when the plant density was maintained, increased grain yield in the high crop management system in the first year (10\%) and in the very high in both years (5 and $14 \%$ in the first and second years, respectively). Thus, when there were increases in grain yield, they were small, did not depend on the hybrid and were only manifested in crop management systems with grain yield greater than $10.0 \mathrm{t} \mathrm{ha}^{-1}$. The absence of hybrid and row spacing interaction in five of the six experiments contradicted results obtained by Argenta et al. (2001a), who reported greater potential in grain yield response to narrow row spacing for hybrids with erect leaves, such as Flash. On the other hand, the magnitude of yield increases obtained with row spacing reduction confirmed results obtained by Mundstock (1977), Sangoi (1990), Sangoi et al. (1998), Teasdale (1998), Argenta et al. (2001a and b), Flesh \& Vieira (2004) and Balbinot-Júnior \& Fleck (2005a).

The lack of grain yield response to the reduction of row spacing from 0.8 to $0.4 \mathrm{~m}$ in most trials (Table 2) showed that the potential benefits of narrow row spacing may not result in higher productivities, specially when yield levels were low or medium $(<8.0$ $\left.t h a^{-1}\right)$. The absence of positive response to narrow row spacing under less favorable crop management systems showed that there were other factors, such as water and nutritional shortages, lower grain yield potential, unsuitable sowing time and limitations in weed, pest and disease control, which can limiting crop yield more than the plant arrangement.

The behavior of grain yield observed especially in the medium crop management system did not support the argument presented by Fundação Rio Verde (2002) that more uniform distribution among plants, due to narrow row spacing, increased grain yield under conditions of water and nutritional limitations, due to the more homogeneous placing of the root system, better soil use and greater efficiency in water and nutrient absorption. A more uniform spatial distribution among plants was an efficient strategy to lift maize productivity only under satisfactory moisture and soil fertility conditions, when grain yield was high. In these cases, the more equidistant plant arrangement in the row provided by narrow row spacing resulted in a better use of the environmental resources like water, light and nutrients. This conclusion is in agreement with Strieder et al. (2007), who carried out a study in the same area of the present research, assessing the effect of narrow row spacing on maize hybrids with different leaf architecture and in a high grain yield potential.

The number of grains per area also increased only in the experiments where row spacing reduction increased grain yield (in the first year with the high crop management system and the two years with very high crop management systems) (Table 2). The number of grains per area was the component that best explained the variation in grain yield with narrow row spacing. The same trend was reported by Sangoi et al (2002) and Madonni \& Otegui (2004).

Kernel crude protein content was not affected by narrow row spacing in five of the six experiments (Table 3). Maintaining the plant density, the more uniform spatial distribution between plants increased kernel crude protein content only in the second year in the medium crop management system which was the trial with the lowest grain yield. Thus, the effects of row spacing on grain yield and on the kernel crude protein contents shows that grain quality increased only in the situation with the lowest grain yield $(2.2 \mathrm{t}$ $\mathrm{ha}^{-1}$ ), while with productivities higher than $8.0 \mathrm{t} \mathrm{ha}^{-1}$, row spacing did not affect this characteristic.

Narrow row spacing can increase maize grain yield under high input crop management systems. In the present study the economic analysis was not to proceed to evaluate if these grain yield increments reflect in a higher economic return of the investments and so, justify the greater amount of expenses in the highest management levels. However other studies conducted in the same locality (Sangoi et al., 2006; 
Forsthofer et al., 2006) demonstrates that higher investments in technology may increase the potential of maize grain yields. In these studies different management levels (low to high) were used and also narrow row spacing on to the highest levels, as in the present study. According the authors, these economic benefits are specially important in the October sowings, like in the present study, when in South of Brazil its possible to have a synergy between the incidence of the maximum solar radiation level with full maize flowering, i.e., when the leaf area index is the highest. Thus, there is highest light interception by the canopy and, according to these authors, the adoption of maize genotypes of higher grain yield potential, the use of greater plant densities and the application of more fertilizers, allow increasing the economic return on maize. Moreover, this cropping practice can also be used by farmers lower capacity to invest in technology due to other potential benefits that include: decrease in weed development and infestation (Tollenaar et al., 1997; Johnson et al., 1998; Argenta et al., 2000), reduced herbicide use and dosage (Forcella et al., 1992; Teasdale, 1998; Balbinot Júnior \& Fleck, 2005b) and decreased the risk of toxic effects caused by fertilizer salinity on the seeds (Fundação Rio Verde, 2002). A further potential advantage is the increased efficiency in soil and water conservation, due to early closure of row spaces in the canopy, decrease in superficial runoff and soil and water losses from erosion (Sangoi et al., 2001; Cogo et al., 2003). Furthermore, narrow rows may increase the efficiency of using equipment on the farm, especially for sower-fertilizers, because they allow a uniform row spacing regulation for sowing the two main summer crops (maize and soybean) without adjustment (Mundstock \& Silva, 2005).

The potential advantages of using closer rows should be counterbalanced by the producer with some limitations because, in addition to frequently not increasing grain yield, adoption of this cropping practice hinders crop treatment application in post emergence and increases production costs, because harvesting platforms and tractor tire diameter need to be adapted to this row spacing. Progress has been made recently in the offer of equipment adapted for maize cropping with narrow row spacing (Argenta et al., 2001b), although the cost of harvesting platforms is still high.

\section{CONCLUSIONS}

Maize grain yield increases were small with narrow row spacing, depended on the growing season, occurred only when grain yields were higher than $10.0 \mathrm{t} \mathrm{ha}^{-1}$ and did not provide more efficient use of the environmental resources when maize yields were low or medium $\left(<8 \mathrm{tha}^{-1}\right)$. The hybrid plant architecture did not interfere in maize grain yield response to narrow row spacing. The number of grains per area was the component mostly associated to grain yield response on narrow row spacing, regardless of plant density, hybrid or crop management system.

\section{ACKNOWLEDGMENTS}

To CNPq for the graduate and undergraduate scholarships, FAPERGS for the undergraduate scholarship and the Syngenta Seeds Company for the research financial support.

\section{REFERENCES}

ARGENTA, G.; SILVA, P.R.F.; BORTOLINI, C.G.; MEROTTOJÚNIOR, A.; FORSTHOFER, E.L.; STRIEDER, M.L. Redução da dose de herbicida utilizada na cultura do milho através da adoção de menor espaçamento entre linhas. Revista Plantio Direto, v.58, p.66-69, 2000.

ARGENTA, G.; SILVA, P.R.F; BORTOLINI, C.G.; FORSTHOFER, E.L.; MANJABOSCO, E.A.; BEHEREGARAY-NETO, V. Resposta de híbridos simples de milho à redução do espaçamento entre linhas. Pesquisa Agropecuária Brasileira, v.36, p.7178, 2001a.

ARGENTA, G.; SILVA, P.R.F.; SANGOI, L. Arranjo de plantas em milho: análise do estado-da-arte. Ciência Rural, v.31, p.10751084, 2001b.

ARGENTA, G.; SANGOI, L.; SILVA, P.R.F.; RAMPAZZO, C.; GRACIETTI, L.C.; STRIEDER, M.L.; FORSTHOFER, E.L.; SUHRE, E. Potencial de rendimento de grãos de milho em dois ambientes e cinco sistemas de produção. Scientia Agrária, v.4, p.27-34, 2003.

BALBINOT-JÚNIOR, A.A.; FLECK, N.G. Competitividade de dois genótipos de milho (Zea mayz) com plantas daninhas sob diferentes espaçamentos entre fileiras. Planta Daninha, v.23, p.415-421, 2005 a.

BALBINOT-JÚNIOR, A.A.; FLECK, N.G. Manejo de plantas daninhas na cultura de milho em função do arranjo espacial de plantas e características dos genótipos. Ciência Rural, v.35, p.245-252, 2005b.

BERGAMASCHI, H.; GUADAGNIN, M.R.; CARDOSO, L.S.; SILVA, M.I.G. Clima da Estação Experimental da UFRGS (e região de abrangência). Porto Alegre: UFRGS, 2003. 77p.

COGO, N.P.; LEVIEN, R.; SCHWARZ, R.A. Perdas de solo e água por erosão hídrica influenciadas por métodos de preparo, classes de declive e níveis de fertilidade do solo. Revista Brasileira de Ciência do Solo, v.27, p.743-753, 2003.

COMISSÃO DE QUÍMICA E FERTILIDADE DO SOLO - CQFS RS/SC. Manual de adubação e de calagem para os Estados do Rio Grande do Sul e Santa Catarina. Porto Alegre: SBCS/Núcleo Regional Sul, 2004. 400p.

DUVICK, D.N.; CASSMAN, K.G. Post-green revolution in yield potential of temperate maize in north-central United States. Crop Science, v.28, p.254-258, 1999.

EMPRESA BRASILEIRA DE PESQUISA AGROPECUÁRIA EMBRAPA. Sistema Brasileiro de Classificação de Solos. Rio de Janeiro, Embrapa-CNPS, 1999. 412p.

FLESCH, R.D.; VIEIRA, L.C. Espaçamentos e densidades de milho com diferentes ciclos no Oeste de Santa Catarina, Brasil. Ciência Rural, v.34, p.25-31, 2004.

FORCELLA, F.; WESTGATE, M.E.; WARNES, D.D. Effect of row width on herbicide and cultivation requirements in row crops. American Journal of Alternative Agriculture, v.7, p.161167, 1992. 
FORSTHOFER, E.L.; SILVA, P.R.F.; STRIEDER, M.L.; MINETTO, T.; RAMBO, L.; ARGENTA, G.; SANGOI, L.; SUHRE, E.; SILVA, A.A. Desempenho agronômico e econômico do milho em diferentes níveis de manejo e épocas de semeadura. Pesquisa Agropecuária Brasileira, v.41, p.399-407, 2006.

FUNDAÇÃO RIO VERDE. Resultados de pesquisa arroz, milho e soja: safra 2001/2. Lucas do Rio Verde: Fundação Rio Verde, 2002. 65p. (Boletim Técnico, 5).

JOHNSON, G.A.; HOVERSTAD, T.R.; GREENWALD, R.E. Integrated weed management using narrow corn row spacing, herbicides, and cultivation. Agronomy Journal, v.90, p.4046, 1998

LOOMIS, R.S.; AMTHOR, J.S. Yield potential, plant assimilatory capacity, and metabolic efficiencies. Crop Science, v.39, p.1584-1596, 1999.

MADONNI, G.A.; OTEGUI, M.A. Intra-specific competition in maize: early establishment of hierarchies among plants affects final kernel set. Field Crops Research, v.85, p.1-13, 2004.

MATZENAUER, R.; MACHADO, F.A. Disponibilidade hídrica para a cultura do milho em anos de El Niño, La Niña e Neutros, nas regiões climáticas do Planalto Médio e Depressão Central do Rio Grande do Sul. Revista Brasileira de Agrometeorologia, v.10, p.67-74, 2002.

MELGES, E.; LOPES, N.F.; OLIVA, M.A. Crescimento, produção de matéria seca e produtividade da soja submetida a quatro níveis de radiação solar. Pesquisa Agropecuária Brasileira, v.9, p.1073-1080, 1989.

MUNDSTOCK, C.M. Milho: distribuição da distância entre linhas. Lavoura Arrozeira, v.229, p.28-29, 1977.

MUNDSTOCK, C.M.; SILVA, P.R.F. da. Manejo da cultura do milho para altos rendimentos de grãos. Porto Alegre: UFRGS/Departamento de Plantas de Lavoura, 2005. 51p.

OTTMAN, M.J.; WELCH, L.F. Planting patterns and radiation interception, plant nutrient concentration, and yield in corn. Agronomy Journal, v.81, p.167-174, 1989.

REUNIÃO TÉCNICA ANUAL DO SORGO, 33.; REUNIÃO TÉCNICA ANUAL DO MILHO, 50., Porto Alegre, 2005. Anais. Porto Alegre: FEPAGRO/EMATER, 2005. 155p.

RITCHIE, S.W.; HANWAY, J.J.; BENSON, G.O. How a corn plant develops. Ames: Iowa State University, 1993. 21p. (Special Report, 48). Available at: http://maize.agron.iastate.edu/ corntitle.html. Accessed 19 Jan. 2006.

SANGOI, L. Arranjo de plantas e características agronômicas de genótipos de milho em dois níveis de fertilidade. Pesquisa Agropecuária Brasileira v.25, p.12-14, 1990.

SANGOI, L.; ALMEIDA, M.L.; SILVA, P.R.F; ARGENTA, G. Bases morfofisiológicas para maior tolerância dos híbridos modernos de milho a altas densidades de plantas. Bragantia, v.61, p.101110, 2002.
SANGOI, L.; ENDER, M.; GUIDOLIN, A.F.; ALMEIDA, M.L.; HEBERLE, P.C. Influence of row spacing reduction on maize grain yield in regions with a short summer. Pesquisa Agropecuária Brasileira, v.36, p.861-869, 2001.

SANGOI, L.; ENDER, M.; MEROTTO JÚNIOR, A.; ALMEIDA, M.L. Redução do espaçamento entrelinhas para cultivares de milho de ciclos contrastantes em duas épocas de semeadura. In: REUNIÃO ANUAL DO MILHO E SORGO, 42., Erechim, 1997. Anais. Porto Alegre: FEPAGRO/EMATER, 1998. p.26-30.

SANGOI, L.; ERNANI, P.R.; SILVA, P.R.F. DA; HORN, D.; SCHMITT, A.; SCHWEITZER, C.; MOTTER, M. Rendimento de grãos e margem bruta de cultivares de milho com variabilidade genética contrastante em diferentes sistemas de manejo. Ciência Rural, v.36, n.3, p.747-755, 2006.

SANGOI, L.; SILVA, P.R.F. Alta densidade e espaçamento entrelinhas reduzido em milho. Cultivar, v.87, p.10-15, 2006.

SAS INSTITUTE. SAS/STAT user's guide: version 6.4. Cary: SAS Institute, 1996. v.1.

SILVA, P.R.F.; ARGENTA, G.; REZERA, F. Resposta de híbridos de milho irrigado à densidade de plantas em três épocas de semeaadura. Pesquisa Agropecuária Brasileira, v.34, p.585592, 1999.

SILVA, P.R.F.; SANGOI, L.; ARGENTA, G.; STRIEDER, M.L. Importância do arranjo de plantas na definição da produtividade do milho. Porto Alegre: UFRGS/Departamento de Plantas de Lavoura, 2006. 64p.

STRIEDER, M.L.; SILVA, P.R.F; ARGENTA, G.; RAMBO, L.; SANGOI, L.; SILVA, A.A.; ENDRIGO, P.C. A resposta do milho irrigado ao espaçamento entrelinhas depende do híbrido e da densidade de plantas. Ciência Rural, v.37, p.634-642, 2007.

TEASDALE, J.R. Influence of corn population and row spacing on corn and velvetleaf (Abutilon theophrasti) yield. Weed Science, v.46, p.447-453, 1998.

TEDESCO, M.J.; GIANELLO, C.; BISSANI, C.A.; VOLKWEISS, S.J.; BOHNEN, H. Análises de solo, plantas e outros materiais. 2 ed. Porto Alegre: UFRGS/ Departamento de Solos, 1995. 174p. (Boletim Técnico de Solos, 5).

TOLLENAAR, M.; AGUILERA, A.; NISSANKA, S.P. Grain yield is reduced more by weed interference in an old than in a new maize hybrid. Agronomy Journal, v.89, p.239-246, 1997.

TOLLENAAR, M.; LEE, E.A. Yield potential, yield stability and stress tolerance in maize. Field Crops Research, v.75, p.161169, 2002.

Received December 11, 2006

Accepted January 07, 2008 